\title{
Teamwork and Organizational Innovation: The Moderating Role of the HRM Context
}

\author{
Doris Fay, Helen Shipton, Michael A. West and \\ Malcolm Patterson
}

Evidence is accumulating on the role of teams in shaping a variety of business outcomes, but our knowledge on the effect of teamwork on organizational innovation is still evolving. This study examines whether the extent to which two staff groups are organized in teams (production staff and management/administrative staff) affects organizational innovation and whether human resource management (HRM) systems, which can be of facilitating or constraining nature, enhance the teamwork/innovation relationships. Hypotheses were tested with lagged and longitudinal data derived from 18 to 45 organizations from the UK manufacturing sector. Results suggest that the more widespread the use of teamwork in organizations, the higher the level of organizational innovation. Furthermore, this effect depends, particularly for production teams, on the overall quality of the HRM systems that exist in their organizations. Teamwork/innovation relationships are further moderated (for management and administrative teams) by an HRM practice that provides teams with time for thoughtful reflection. Thus, HRM systems can be of more or less facilitating or constraining nature for teams in organizations.

\section{Introduction}

Tncreasing worldwide competition, highly Ivolatile markets and ever higher customer expectations make it necessary for organizations to be open to the prospect of innovation. Not only the development of new products, but also the ability to quickly adopt new technologies and to continuously improve production methods and procedures appear to be vital for organizations to prosper against this backdrop (Chaney \& Devinney, 1992; Banbury \& Mitchell, 1995). To deal with these challenges, many organizations have adopted organizational structures that involve the use of teams. For example, in UK manufacturing, 65 per cent of workforces are reported to work in teams, while a US survey revealed that this figure is as high as 48 per cent across all sectors (Cully et al., 1999; Benders, Huijgen \& Pekruhl, 2002). The purpose of this study is to explore the role of teamwork for organizational innovation.
The optimistic rhetoric of teamwork argues that the more widespread teamwork is in an organization, the higher the level of organizational innovation; however, few studies have explicitly tested this assumption (Mohrman, Cohen \& Mohrman, 1995; West \& Markiewicz, 2004). While there is a large body of research on teams in relation to innovation, which explores characteristics of teams, their processes, members, environment and work organizations and how this affects teams (see meta-analysis by Hülsheger, Anderson \& Salgado, 2009), comparatively fewer studies have looked at the use of teamwork in organizations and how it affects the organization's innovativeness (Naveh \& Erez, 2004).

Furthermore, the research literature on the benefit of teamwork is less conclusive than desirable. Teamwork can be accompanied by unwanted phenomena that result in performance loss or poor decision making (Aldag \& Fuller, 1993; Karau \& Williams, 1993). Demographic differences in teams can result in the 
development of 'faultlines' (Lau \& Murnighan, 2005), resulting in competition and conflict within a team. It is a truism that there are large variations in team performance to the point of complete failure (Hackman, 1990). Thus, while teamwork in itself appears to bear some risks, scholars of teamwork have furthermore argued that the organizational context within which teams operate bears some additional risks. The context influences their effectiveness as it can be of a constraining or facilitating nature for the teams (Hackman, 1990; Sundstrom, De Meuse \& Futrell, 1990; Guzzo et al., 1992). Context can be of constraining nature if there is a lack of alignment with organizational systems. Then, teams cannot fulfil their full potential to make contributions to organizational goals. The human resource management (HRM) perspective argues more specifically, that in order to enhance organizational effectiveness, teamwork has to be applied in conjunction with other, so-called 'high performance' practices (such as sophisticated selection, effective learning and development, performance-related pay and opportunities for employee involvement) which would remove many constraints for teams to work effectively (Pfeffer, 1998). Research shows that teamwork effectiveness depends on accompanying human resource practices (Richter, Dawson \& West, 2011); however, we know little with regard to organizational innovation.

Recent research supports the role of teamwork for organizational innovation (Jiang, Wang \& Zhao, 2012). One study explored specifically the role of teamwork for organizational innovation in products and technical systems (Shipton et al., 2006). This study drew on a set of organizations where the use of teamwork ranged from not using teamwork at all (i.e., zero per cent of staff organized in teams) to having 100 per cent of staff organized in teams. The study found that the more widespread the use of teams, the higher the level of organizational innovation. The purpose of this paper is to build upon this study and to expand it in three ways. First, we reanalyse Shipton et al.'s (2006) results to explore the significance of the type of team whether, for example, teams drawn from those directly involved in manufacturing influence innovation to a greater or lesser extent than management/administrative teams. The second area that we examine here is the HRM context in which the teams operate. This context can be of a constraining nature for teamwork or facilitate its effectiveness. Thus we test the extent to which HRM systems moderate teamwork/innovation relationships. Are teams more effective (in terms of their contribution to innovation) where they are part of a 'high quality' HRM system, or does the wider context have little bearing on this outcome? Thirdly, we examine the role of a team-oriented HRM practice - namely providing teams with reviewing time - on the propensity of teams to enhance innovation.

\section{Innovation}

Innovation is defined as the development (or the adaptation) and implementation of an idea, which is useful and new to the organization at the time of adoption (van de Ven, 1986; Amabile, 1996; Damanpour \& Schneider, 2006). Innovation relates to new products and services, production methods and procedures, production technologies, and to administrative changes. In this study, we focus on organizational innovations which pertain to products and technical systems (i.e., production processes and procedures). The two key factors for a successful innovation are an organization's ability to be creative and the ability to successfully manage the complex process of turning creative ideas into reality (Zaltman, Duncan \& Holbek, 1973; van de Ven, 1986; West et al., 2002; Damanpour \& Schneider, 2006).

Creativity is at the very heart of any innovation. It is a new idea - generated within the organization or imported from outside - that stands at the beginning of the innovation process and, furthermore, creativity is important while turning the idea into a new product, service, procedure or working method (Amabile, 1996). When turning a new idea into reality, numerous barriers and problems need to be overcome and creativity is required to solve all the problems and successfully deal with errors and failures (Klein \& Sorra, 1996). It seems that all organizational functions, not just research and development specialists, can be a source of inspiration (Trott, 2005). Organizations support the development of new ideas when they have mechanisms in place, such as teamwork, that bring different perspectives together, that can fertilize each other for creative ideas to emerge, and time and resources that allow new ideas to be explored (Ancona \& Caldwell, 1992; Amabile, 1996; Un \& Cuervo-Cazurra, 2004).

The second challenge relates to the complex process of turning a creative idea into an outcome. Beyond the creative idea at its beginning, the innovation process encompasses a matching of the idea to a problem or opportunity, a decision to adopt it, the implementation of the idea and finally the routine use (Zaltman, Duncan \& Holbek, 1973). The 
unfolding of the innovation process is best described as a long series of loops, as nonsequential and as a process that continues through several iterations (King, 1992). This discontinuous nature implies that involvement, knowledge and expertise of several organizational functions are required simultaneously at any given time in an innovation process. Teamwork presents an opportunity to bring together the diverse knowledge and skills required to see an innovation through to completion (Un \& Cuervo-Cazurra, 2004).

\section{The Use of Teamwork and Organizational Innovation}

A team is defined as a working arrangement in which individuals work interdependently to achieve their goals; where they are collectively accountable for their work outcomes, and where they and others see them as an intact social identity (Mohrman, Cohen \& Mohrman, 1995; Cohen \& Bailey, 1997). In the manufacturing sector, the area upon which our research is built, work teams typically exist on a continuous basis to deal with day-to-day tasks and to make and implement suggestions to enhance performance. We are concerned here with work teams that are relatively autonomous and self-directed. Self-directed teams choose their course of action within prescribed constraints and have responsibility for task allocation and achievement of specified outcomes (Sundstrom, De Meuse \& Futrell, 1990; Mohrman, Cohen \& Mohrman, 1995; Cohen \& Bailey, 1997). We propose that teamwork can enhance innovation in two ways: first, teamwork changes the affective experiences, cognitions and attitudes of individuals, which in turn enhance their creativity and their ability to solve problems creatively; and second, teamwork is associated with structural changes to the organization such that the flow of ideas and knowledge is enhanced and organizations become more flexible.

On the first point, self-directed teamwork promotes a cross-fertilization of ideas and shapes 'positive mood' (Naveh \& Erez, 2004). According to this argument, bringing people together to work on shared objectives produces a divergence of orientation, experiences and knowledge that will promote more comprehensive processing of information, and a search for a wider variety of options (Jackson, 1996; Milliken \& Martins, 1996). Task-related diversity benefits team performance, and this exposure to diversity and variety is also beneficial for creativity (Mannix \& Neale, 2005; Horwitz \& Horwitz, 2007). Furthermore, the role of knowledge sharing and learning for innovation processes has frequently been highlighted (Basadur \& Gelade, 2006; MacCurtain et al., 2010), and teamwork contributes to this. It makes it easier for team members to leverage each other's knowledge and appears to enhance the creation of new knowledge (Reagans, Argote \& Brooks, 2005).

One core aspect of self-directed teams is the autonomy they have over work operations (Morgeson et al., 2006). Autonomy leads to a sense of responsibility and increases intrinsic motivation, which in turn is associated with conception and implementation of new ideas (Amabile, 1996; Urbach, Fay \& Goral, 2010). Furthermore, teamwork may also benefit creativity because individuals tend to experience positive feelings through working in teams (relative to more traditional working arrangements; Wall et al., 1986; see also the metaanalysis by Richter, Dawson \& West, 2011). This is an attitudinal state that is itself associated with successful creative endeavour (Isen, Daubman \& Nowicki, 1987; Davis, 2009).

The second mechanism by which teamwork contributes to innovation relates to the way work is organized and the way the organization is structured when teamwork is in place. Matrix structures or team-based organizations have been considered as structures that encourage lateral communications and that in turn facilitate overcoming segmented structures (Anderson \& King, 1993). Teamwork breaks down relatively impermeable boundaries between subunits through lateral linkages. Lateral linkages across teams can be implemented through use of integrating teams, cross teams, liaison roles and overlapping team memberships (Mohrman \& Mohrman, 1994; Mohrman \& Quam, 2000). This allows multiple viewpoints to converge upon a problem. In the process of turning initial ideas into innovations, those lateral linkages help ideas to be shared and discussed, so that the multiple perspectives and expertise may help good ideas to mature and poor ideas to be abandoned faster. Lateral linkages result in stronger internal communication, which in turn has been shown to be associated with organizational innovation (Damanpour, 1991).

Furthermore, more widespread use of teamwork tends to be associated with flatter organizational structures, because teamwork is related to a change in reporting relationships (Harris \& Beyerlein, 2005). If good ideas emerge, they have to be brought to the attention of key decision makers in order to gain approval and resources for further experimentation, or so that a decision to adopt can be made at the appropriate organizational level (Zaltman, Duncan \& Holbek, 1973). Flatter organizational structures facilitate escalating 
ideas to key decision makers. This allows decisions to be made more quickly, so that ideas can be turned into innovations before they become outdated.

Finally, the structural changes, in particular the heightened lateral linkages and internal communication, not only 'facilitate dispersion of ideas within an organization', they also create 'an internal environment favorable to the survival of new ideas' (Damanpour, 1991, p. 559). The receptivity for new ideas may be changed, which is not only relevant in the decision-making phase but also in the implementation phase (Klein \& Sorra, 1996). To summarize, teamwork may support organizational innovation through higher creativity which is relevant for both ideation and overcoming problems in the course of innovation implementation (cf. Klein \& Sorra, 1996), through organizational structures that support the fast refinement and maturing of ideas, and through an elevated receptivity to innovative ideas (Damanpour, 1991).

\section{Teamwork for Different Staff Groups}

Shipton et al.'s (2006) analysis of manufacturing organizations demonstrated that the extent of teamwork - ranging from organizations not using teamwork at all to having 100 per cent of staff organized in teams - was related to organizational innovation. However, their analysis did not take into consideration that the effect of teamwork could differ depending on the organizational level at which the teams were operating. Teamwork was assessed in terms of the extent to which staff was organized in teams, regardless of organizational level. We distinguish here between two staff categories that function at different organizational levels: (1) staff working in production and (2) management/administrative staff. Our review of the literature on the innovation process has pointed out that both categories are involved in and relevant for a successful innovation process. How they contribute, however, may differ. This is related to the fact that management and administrative teams differ from production teams not only in where they are located in the organizational hierarchy, but also in their level of knowledge diversity and in the activities required of them.

Management and administrative teams are more likely to exhibit higher diversity in taskrelated knowledge and expertise than production teams. Having people working together with high levels of knowledge diversity may result in more and better idea development, and in being better able to identify and resource the best ideas (Jackson, 1996; Milliken \& Martins, 1996; Un \& Cuervo-Cazurra, 2004; Mannix \& Neale, 2005; Fay et al., 2006). Managerial staff are typically charged with exploration activities (March, 1991); if teamwork supports the development of new ideas, those ideas emerge in an environment where they are most likely to become used. Management and administrative teams might primarily affect innovation through providing ideas, resourcing the best ideas and initiating their implementation.

Production teams, on the other hand, are more homogeneous in terms of their members' knowledge, skills and abilities. Use of production teams represents an opportunity to bring individuals together who may previously have worked largely in isolation. Production teams may therefore more effectively overcome the segmented structures associated with traditional ways of working, breaking down impermeable boundaries between sub-units and promoting a more fertile and flexible environment. Because of strengthened lateral linkages among and between teams, initial new ideas are more easily enriched and refined through the different perspectives they can be exposed to; thus, production teams can also contribute to organizational innovation by providing ideas. More important, however, is probably the role of production teams for effective implementation. Stronger lateral linkages make production teams more effective in overcoming problems during implementation; the presumed heightened creativity contributes to this. Thus, we propose that both production and management teams play a positive role in the innovation process. In the present study we test on an exploratory basis whether they differ in the strength of effect.

Hypothesis 1: The extent to which both management/administrative staff and production staff are organized in teams is positively related to innovation.

Research Question 1: Does the effect of management/administrative staff being organized in teams differ from the effect of production staff being organized in teams?

\section{Constraining or Facilitating Context: The Role of HRM for the Effect of Teamwork}

Numerous scholars have argued that the organizational context within which teams operate will influence their performance and effectiveness as it can be of a constraining or 
facilitating nature for the teams (Hackman, 1990; Sundstrom, De Meuse \& Futrell, 1990; Guzzo et al., 1992). For example, it is a truism that teamwork is prone to failure if the reward system does not include rewards for collaboration and achievement of team goals (West \& Markiewicz, 2004). We propose that the quality of the HRM systems is a key contextual variable that influences whether teams can develop their full potential. Here we define the quality of HRM systems as the extent to which HRM systems are systematically guided by a strategy and the extent to which they are endorsed and resourced.

More specifically, high-quality HRM systems are characterized by a clear strategy that guides the intake of employees and that oversees the development of their knowledge, skills and abilities, and by practices that act upon the strategy (i.e., recruitment strategies, induction, training, performance management). They have been shown to contribute to organizational effectiveness and performance (Huselid, 1995; Applebaum et al., 2000; Guthrie, 2001; Den Hartog \& Verburg, 2004) and there is increasing evidence that HRM systems have an effect on innovation (Laursen \& Foss, 2003; Lau \& Ngo, 2004; Shipton et al., 2005).

We conceptualize HRM as the 'context' in which teams operate and which can facilitate or impair the effect of teamwork for innovation. High-quality HRM systems clearly communicate the direction of the company to employees. They effectively signal to employees (whether it be through training, appraisal or performance-based pay) what behaviours are recognized and valued and they provide the support to individuals as they respond to the signals they receive. If teamwork helps to generate more innovative ideas, helps to circulate them through the organization more efficiently to refine and mature them, high-quality HRM systems will enhance this effect by giving clear guidance and feedback as to what kind of ideas the organization needs. Such systems enable staff to understand organizational needs, to focus on ideas that fit the organization's strategy. In contrast, lowquality HRM systems constrain teams from fulfilling their full potential.

Hypothesis 2: The overall quality of HRM systems moderates the effect of the extent of teamwork on innovation such that the effect of teamwork is stronger the higher the quality of HRM systems.

Research on team innovation finds increasing evidence for the relevance of team reflexivity for innovation. Team reflexivity directly affects team innovation (Somech, 2006;
MacCurtain et al., 2010), and it also helps teams to make effective use of their potential. For example, having diverse or dissenting opinions in a team contributes to team innovation provided the team shows a high level of reflexivity (De Dreu, 2002), and a similar effect has been found for team knowledge diversity (Fay et al., 2006). Furthermore, higher team reflexivity helps to make more effective use of job control in the course of making innovative contributions (Urbach, Fay \& Goral, 2010).

One specific HRM practice that could be conducive to the development of team reflexivity is the availability of reviewing time (see Gersick's findings on teams' spontaneous use and benefit of reviewing time; Gersick, 1988, 1989). One of the reasons why teamwork should benefit innovation is that it brings together individuals with different skills and information, functional and educational backgrounds. This high level of knowledge diversity and the associated diverse perspectives have the potential to result in more innovative approaches. We argue that the benefit of the diverse perspectives is enhanced when people take time to deliberate and reflect on them (De Dreu, 2002). Diverse knowledge needs cognitive effort for integration before it can result in ideas or solutions of high quality. In particular, a high level of dissimilarity, which can involve a lack of shared mental models, can stand in the team's way (Mathieu et al., 2000). Dissimilar perspectives need to be reconciled before one can make use of them. Reflexivity helps to uncover unshared mental models and to achieve cognitive consensus (van Ginkel, Tindale \& van Knippenberg, 2009). Research on knowledge diversity showed that teams only benefited from their diversity in terms of innovation quality when team processes included high levels of reflexivity (Fay et al., 2006).

HRM practices can provide teams with opportunities to enhance their reflexivity. Teams that are given time to review their processes, for example in days away from the pressures of day-to-day work, are more likely to develop reflexivity (Gevers, van Eerde \& Rutte, 2001). We suggest that there is an interaction between the extent of teamwork and the use of HRM practices that allow the development of reflexivity. We propose that the extent to which teamwork enhances organizational innovation is enhanced through teams using time to review their work because reviewing time and the presumed development of reflexivity allows teams to make better use of their potential.

Hypothesis 3: Teams taking time out for reviewing moderates the effect of 
teamwork on innovation such that the effect of teamwork is higher when teams take time out.

\section{Method}

\section{Sample}

This paper re-analyses a subset of companies that participated in a longitudinal study conducted in the UK (Shipton et al., 2006). A total of 111 manufacturing companies, from electronics and communications, food and drink and mechanical engineering, participated in the full study (West et al., 1999). Here we report findings of data gathered in managerial interviews and surveys in 45 companies. The size of the sub-sample reduces further when including longitudinal data (i.e., prior innovation and prior productivity). We could not include all companies in the analysis because of missing data (e.g., not all companies that took part in the interview returned the survey); second, some of the measures could not be assessed in all organizations (e.g., companies that did not use teamwork could not be used for the analyses that looks at the effect of 'team reviewing time'). A comparison of companies included in the analyses presented here with all other companies with regard to all study variables did not yield any significant differences $(p>0.05)$.

\section{Measures}

Data were collected at different points in time. At Time 1, organizational size, innovation and profitability were assessed. Two years later (Time 2), levels of teamwork and the HRM practices were assessed. The outcome variables, product innovation and innovation in technical systems were assessed another year later (Time $3=$ Time $1+$ three years).

The independent variables - extent of teamwork, quality of HRM systems and use of team reviewing - were collected with structured interviews. Companies were briefed before the researchers' visit on what areas the interview schedule covered and were asked to determine which senior managers were best placed to answer questions in each of the interview schedule areas. Data presented here are based on two of several sections of the interview. The interview section covering work design was mostly conducted with the production manager; this interview section provided information on teamwork. The interview section on human resources was conducted with the person primarily responsible for HRM (e.g., personnel director). Researchers were provided with an extensive interview schedule which assessed the relevant information (as described below) and the rating scales. The researchers crosschecked information received from interviewees with additional information taken from company documents. The researchers' visit also included a tour of the manufacturing facility; this tour was used to verify the data obtained in the interviews.

\section{Extent of Teamwork}

Extent of teamwork was assessed by asking the interview partner for the percentage of production staff and percentage of management/ administrative staff working in teams. The respondent was asked to 'refer only to stable teams'.

\section{Overall Quality of HRM}

The quality of HRM systems is a scale based on four rating items, filled in by the researchers on the basis of information collected in an in-depth interview on HRM. The interview explored the nature of HRM activities in the areas of recruitment and selection; induction; training; performance management (appraisal and reward); and promotion. Furthermore, it included an assessment of the HRM strategy, taking into account whether a formal HR strategy is endorsed by the top management and whether there is a commitment to a strategic planning process for the implementation of HR strategy and policy. The aspects of the HRM systems explored are similar but not identical to a high performance work system (HPWS) (see, e.g., Den Hartog \& Verburg, 2004).

Using this information, researchers rated on five-point scales the following aspects: 'How much effort is put into HRM?' ( 1 = 'none at all' to $5=$ 'a very great deal'); 'How well planned is the HRM policy?' ( 1 = 'not at all planned' to 5 = 'excellently planned'); 'How sophisticated is the HRM policy?' $(1=$ 'not at all sophisticated' to $5=$ 'very highly sophisticated'); 'How effective overall is the HRM policy?' ( 1 = 'not at all effective' to $5=$ 'very effective'). Reliability of the measure was very good (Cronbach's alpha $=0.93$ ).

\section{Reviewing Time for Teams}

Information on 'reviewing of team functioning' was also obtained in the interview. Researchers assessed separately for production teams and management/administrative teams the length of time teams take out for team reviewing each year, using an ordinal rating format $(1=$ 'no time take out', $2=$ 'one day', $3=$ 'two days', $4=$ 'one week', $5=$ 'more than 
one week'). Since one cannot use items based on ordinal answer formatting in regression analyses, and the responses were highly skewed, they were transformed into binary items. One item assessed whether or not management/administrative teams would take time out to review their team functioning and the second item assessed the same for production teams.

\section{Outcome Variables: Product Innovation and Innovation in Technical Systems}

Level of innovation was gathered via a postal questionnaire sent to senior managers. Innovation was assessed twice; at Time 1 and Time 3 . Respondents were asked to provide information on organizational change, relating to changes in products made by the organization, and changes in production technology and procedures. Information was collected with open questions and rating scales. Based on this information, three trained researchers working independently provided ratings of product innovation and innovation in technical systems using a 7-point Likert scale from $1=$ 'not at all innovative' to $7=$ 'extremely innovative' (Shipton et al., 2006). Inter-rater agreement was tested by calculating ICC2. For innovation in products, ICC2 was $0.88 ; F$ $(36,72)=24.04, p<0.00$; and for innovation in technical systems ICC2 was 0.70; $F$ (36, $72)=9.67, p<0.00$. Agreements were sufficiently high to justify aggregation of the innovation ratings across raters (Klein et al., 2000), producing one score for innovation in products and one for innovation in technical systems.

The item product innovation is based on the following information: estimates of the number of entirely new and adapted products developed in the last two years; percentage of production workers involved in making the new products; current sales turnover accounted for by the new products; and the extent to which production processes had been changed to accommodate the new products.

The item innovation in technical systems is based on information collected with regard to changes in production technology, production methods and products. Specifically, it took account of the number of newly introduced technologies (i.e., $\mathrm{CNC}$, robots, self-feeding machines, etc.); how different the change was for the organization, the magnitude of change; and it took account of the number of changes in production procedures (e.g., just-in-time management, total quality management, or information scheduling and planning systems); and the novelty and magnitude of those changes. This measure incorporates all aspects of change (products and technology), and is thus a very comprehensive measure.

\section{Control Variable}

Size and profitability could be confounding variables affecting both independent and dependent variables; they are therefore controlled for in the analyses. For example, metaanalyses showed that size facilitates organizational innovation (Damanpour, 1996, 2010; Damanpour \& Schneider, 2006); at the same time, higher organizational size may increase the necessity to move towards more flexible structures. A firm's financial capability facilitates making investments required for both innovation as well as for the implementation of teamwork (Harris \& Beyerlein, 2005). Size was assessed by the number of full-time equivalent employees; profitability was measured with real profits per employee over the three years leading up to Time 1 .

\section{Analytical Strategy for Main Hypotheses}

In the analyses presented here, the predictors - HR practices and teamwork - were assessed at Time 2, the measure of innovation was obtained at Time 3. Even though the predictors were assessed prior to the dependent variable, drawing causal conclusions is not sufficiently justified. For example, a positive association between teamwork and innovation could be the result of teamwork enhancing innovation (as put forward in Hypothesis 1 ), or reverse causality could account for this. Organizations that had been successful innovators in the past could have been more ready to experiment with other forms of work organization, for example, with teamwork. A rigorous longitudinal analysis that includes assessments of innovation and organizational performance prior to Time 2 would reduce this problem. In this study, the data collected at Time 1 also included measures of innovation and profitability. This allows controlling for past organizational performance and past levels of innovation when predicting innovation at Time 3. However, the Time 1 data on profitability and innovation is only available for a small number of organizations. We therefore test each hypothesis twice: first, by predicting innovation at Time 3 from HR practices at Time 2 (which we call 'lagged analysis'); second, by including productivity and innovation at Time 1 as control variables (called 'longitudinal analysis'). The downside to the longitudinal analysis is that there was more missing data, reducing the sample size to $18-26$ organizations. 


\section{Results}

Hypotheses were tested with multiple and moderated hierarchical regression analysis. Due to the comparatively small number of cases, especially for moderated regression analysis, we adopt a probability level of 0.10 . Table 1 displays correlations of all study variables.

\section{Test of Hypotheses}

Results of all hierarchical regression analyses are displayed in Table 2 (for innovations in products as dependent variable) and Table 3 (for innovations in technical systems as dependent variable). The regression analyses show that the extent of teamwork in management/administrative staff on the one hand and of production staff on the other hand explain together significant proportions of variance in both measures of innovation. The patterns of beta coefficients consistently indicate that only teamwork for management/ administrative staff plays a significant role. Extent of teamwork for management/ administrative staff was positively related to innovation, while the beta coefficient of teamwork for production staff was never significant and of very small size. This result does not fully support Hypothesis 1. In terms of our Research Question 1 the results imply that there is only an impact of the extent of management/administrative staff being organized in teams.

In the following analyses, we tested each hypothesis separately for extent of teamwork in management/administrative staff and for extent of teamwork of production staff. We decided to proceed that way because of the unfavourable ratio of cases to predictor variables; testing two interaction effects in one analysis would have overstretched the data.

Hypotheses 2 and 3 look at the context in which the teams work. Hence, organizations without teamwork were not included in the analysis which reduces the number of cases in comparison to the previous analyses. Hypothesis 2 assumed that the quality of HRM systems enhances the effect of the extent of teamwork on innovation. We found consistent support for production staff: a significant interaction term emerged for both types of innovation and in both the lagged (Table 2, column I; product innovation: $\beta=1.625$, $\Delta R^{2}=0.121, p<0.05$; Table 3, column I; innovation technical systems: $\beta=1.511, \Delta R^{2}=0.104$, $p<0.05)$ and the longitudinal analyses (Table 2, column II; product innovation: $\beta=1.566, \Delta R^{2}=0.099, p<0.10$; Table 3, column II; innovation technical systems: $\beta=1.731$, $\left.\Delta R^{2}=0.123, \quad p<0.10\right)$. For management/ administrative teams, the picture was less consistent. While there were significant interactions in the longitudinal analyses, the effect failed to reach significance in the lagged analysis (probability value of interaction term for product innovation $p=0.112$; for innovation in technical systems $p=0.139$ ).

Following Aiken and West (1991), we produced the plotted interactions (see Figures 1 and 2. They showed that increasing levels of teamwork is associated with increasing levels of innovation, provided there is a high-quality HRM system in place.

Hypothesis 3 tested the effect of reviewing team functioning on the relationship of teamwork and innovation. There was consistent support for the hypothesis for management/

Table 1. Means, Standard Deviations and Correlations of All Study Variables

\begin{tabular}{|c|c|c|c|c|c|c|c|c|c|c|c|c|}
\hline & $\mathbf{M}$ & SD & 1 & 2 & 3 & 4 & 5 & 6 & 7 & 8 & 9 & 10 \\
\hline 1 Extent teamwork ${ }^{\mathrm{a}}$ man./admin staff & 37.56 & 38.78 & & & & & & & & & & \\
\hline 2 Extent teamwork production staff ${ }^{b}$ & 58.42 & 41.09 & $0.57^{* *}$ & & & & & & & & & \\
\hline 3 Quality HRM & 2.93 & 0.87 & $0.48^{* *}$ & $0.59^{* *}$ & & & & & & & & \\
\hline 4 Taking time out man/admin. teams $\mathrm{s}^{\mathrm{c}}$ & 0.20 & 0.41 & $0.27+$ & 0.16 & $0.38^{*}$ & & & & & & & \\
\hline 5 Taking time out production teams ${ }^{c}$ & 0.15 & 0.37 & 0.25 & 0.25 & $0.51^{* *}$ & $0.54^{* *}$ & & & & & & \\
\hline 6 Innovation products & 2.73 & 1.37 & $0.31^{*}$ & 0.19 & $0.30^{*}$ & 0.20 & $0.38^{*}$ & & & & & \\
\hline 7 Innovation technical systems & 3.13 & 0.83 & $0.53^{* *}$ & $0.34^{*}$ & $0.42^{* *}$ & 0.09 & $0.39^{*}$ & $0.69^{* *}$ & & & & \\
\hline 8 Organizational size $(\operatorname{lgn})$ & 5.10 & 0.65 & -0.07 & 0.03 & $0.44^{* *}$ & $0.30+$ & $0.51^{* *}$ & 0.22 & 0.09 & & & \\
\hline 9 Prior profitability & 3.17 & 5.46 & 0.16 & 0.11 & 0.21 & 0.21 & $0.33+$ & -0.03 & -0.13 & 0.29 & & \\
\hline 10 Prior product innovation & 2.74 & 1.29 & $0.39^{*}$ & 0.25 & $0.43^{*}$ & 0.28 & 0.28 & $0.52^{* *}$ & $0.34+$ & 0.08 & -0.12 & \\
\hline 11 Prior innov. technical systems & 3.25 & 1.11 & 0.24 & 0.17 & 0.18 & 0.14 & 0.14 & 0.14 & 0.26 & 0.11 & -0.28 & 0.28 \\
\hline
\end{tabular}

Notes:

a Percentage of management/administrative staff organized in teams.

${ }^{b}$ Percentage of production staff organized in teams.

c When teams do not take time out $=0$; otherwise $=1$.

${ }^{*} p<0.05 ;{ }^{* *} p<0.01 ;+p<0.10$; Row 1 to $10 n=39-45$; row 11 to $13 n=25-31$. 
Table 2. Multiple and Moderated Regression of Product Innovation for Lagged (Column I) and Longitudinal (Column II) Effects

\begin{tabular}{|c|c|c|c|c|c|c|c|c|c|c|c|c|c|c|c|}
\hline \multicolumn{2}{|c|}{ Variables entered } & \multicolumn{7}{|c|}{$\mathbf{I}$} & \multicolumn{7}{|c|}{ II } \\
\hline & & $n$ & $R^{2}$ & $F$ & $p$ & $\operatorname{adj} R^{2}$ & $\Delta R^{2}$ & $\beta$ & $n$ & $R^{2}$ & $F$ & $p$ & $\operatorname{adj} R^{2}$ & $\Delta R^{2}$ & $\beta$ \\
\hline \multicolumn{16}{|c|}{ Hypothesis 1} \\
\hline \multirow[t]{4}{*}{ Step 1} & & 45 & 0.050 & 2.253 & 0.141 & 0.028 & & & 26 & $0.341^{*}$ & 3.792 & 0.025 & 0.251 & & \\
\hline & Organizational size & & & & & & & 0.223 & & & & & & & 0.261 \\
\hline & Prior profitability & & & & & & & & & & & & & & $\begin{array}{r}-0.089 \\
0.498^{*}\end{array}$ \\
\hline & $\begin{array}{l}\text { Prior product } \\
\text { innovation }\end{array}$ & & & & & & & & & & & & & & \\
\hline \multirow[t]{3}{*}{ Step 2} & & & $0.158+$ & 2.561 & 0.068 & 0.096 & $0.108+$ & & & $0.515^{* *}$ & 4.251 & 0.009 & 0.394 & $0.174^{*}$ & \\
\hline & $\begin{array}{l}\text { Extent teamwork } \\
\text { man./admin. }{ }^{c}\end{array}$ & & & & & & & $0.333+$ & & & & & & & $0.377^{\mathrm{a}}$ \\
\hline & $\begin{array}{l}\text { Extent teamwork } \\
\text { prod. staff }^{\mathrm{d}}\end{array}$ & & & & & & & -0.007 & & & & & & & 0.154 \\
\hline \multicolumn{16}{|c|}{ Hypothesis 2: Man./admin. staff } \\
\hline \multirow[t]{6}{*}{ Step 1} & & 31 & 0.092 & 0.917 & 0.446 & -0.008 & & & 21 & $0.472 \dagger$ & 2.681 & 0.063 & 0.296 & & \\
\hline & Organizational size & & & & & & & 0.200 & & & & & & & 0.337 \\
\hline & Prior profitability & & & & & & & & & & & & & & -0.294 \\
\hline & $\begin{array}{l}\text { Prior product } \\
\text { innovation }\end{array}$ & & & & & & & & & & & & & & 0.166 \\
\hline & $\begin{array}{l}\text { Extent teamwork } \\
\text { man./admin. }{ }^{c}\end{array}$ & & & & & & & 0.246 & & & & & & & 0.369 \\
\hline & Quality HRM & & & & & & & -0.013 & & & & & & & 0.152 \\
\hline Step 2 & $\begin{array}{l}\text { Teamwork man./ } \\
\text { admin. } \times \text { HRM }\end{array}$ & & 0.178 & 1.406 & 0.260 & 0.051 & 0.085 & $1.389^{\mathrm{b}}$ & & $0.630^{*}$ & 3.980 & 0.016 & 0.472 & $0.159^{*}$ & $2.583^{*}$ \\
\hline \multicolumn{16}{|c|}{ Hypothesis 2: Production staff } \\
\hline \multirow[t]{6}{*}{ Step 1} & & 40 & 0.058 & 0.745 & 0.532 & -0.020 & & & 24 & $0.394 \dagger$ & 2.341 & 0.084 & 0.226 & & \\
\hline & Organizational size & & & & & & & 0.189 & & & & & & & 0.258 \\
\hline & Prior profitability & & & & & & & & & & & & & & -0.145 \\
\hline & $\begin{array}{l}\text { Prior product } \\
\text { innovation }\end{array}$ & & & & & & & & & & & & & & 0.327 \\
\hline & $\begin{array}{l}\text { Extent teamwork } \\
\text { prod. staff }\end{array}$ & & & & & & & -0.092 & & & & & & & 0.086 \\
\hline & Quality HRM & & & & & & & 0.083 & & & & & & & 0.261 \\
\hline Step 2 & $\begin{array}{l}\text { Teamwork prod. } \\
\text { staff } \times \text { HRM }\end{array}$ & & 0.179 & 1.910 & 0.131 & 0.085 & $0.121^{*}$ & $1.626^{*}$ & & $0.493^{*}$ & 2.754 & 0.047 & 0.314 & $0.099+$ & $1.566+$ \\
\hline \multicolumn{16}{|c|}{ Hypothesis 3: Man./admin. staff } \\
\hline \multirow[t]{6}{*}{ Step 1} & & 28 & 0.090 & 0.792 & 0.510 & -0.024 & & & 18 & $0.521+$ & 2.613 & 0.080 & 0.322 & & \\
\hline & Organizational size & & & & & & & 0.162 & & & & & & & 0.405 \\
\hline & Prior profitability & & & & & & & & & & & & & & -0.384 \\
\hline & $\begin{array}{l}\text { Prior product } \\
\text { innovation }\end{array}$ & & & & & & & & & & & & & & 0.183 \\
\hline & $\begin{array}{l}\text { Extent teamwork } \\
\text { man./admin. }{ }^{c}\end{array}$ & & & & & & & 0.110 & & & & & & & 0.343 \\
\hline & Taking time out ${ }^{e}$ & & & & & & & 0.152 & & & & & & & 0.225 \\
\hline Step 2 & $\begin{array}{l}\text { Teamwork man./ } \\
\text { admin. } \times \text { Time } \\
\text { out }\end{array}$ & & $0.297+$ & 2.430 & 0.077 & 0.175 & $0.207^{*}$ & $1.113^{*}$ & & $0.738^{* *}$ & 5.153 & 0.009 & 0.594 & $0.216^{*}$ & $1.335^{*}$ \\
\hline \multicolumn{16}{|c|}{ Hypothesis 3: Production staff } \\
\hline \multirow[t]{5}{*}{ Step 1} & & 37 & 0.145 & 1.870 & 0.154 & 0.068 & & & 22 & $0.527^{*}$ & 3.562 & 0.024 & 0.379 & & \\
\hline & Organizational size & & & & & & & 0.113 & & & & & & & 0.240 \\
\hline & Prior profitability & & & & & & & & & & & & & & -0.321 \\
\hline & $\begin{array}{l}\text { Prior product } \\
\text { innovation }\end{array}$ & & & & & & & & & & & & & & 0.290 \\
\hline & $\begin{array}{l}\text { Extent teamwork } \\
\text { prod. staff }^{\mathrm{d}}\end{array}$ & & & & & & & -0.153 & & & & & & & 0.132 \\
\hline \multirow{2}{*}{ Step 2} & Taking time out ${ }^{e}$ & & 0153 & 1440 & 0243 & 0.047 & 0007 & 0.304 & & $0527^{*}$ & 2791 & 0050 & 0.338 & 0,001 & $0.500^{*}$ \\
\hline & $\begin{array}{l}\text { Teamwork prod. } \times \\
\text { Time out }\end{array}$ & & 0.100 & $1 .+70$ & 0.270 & $0.0+1$ & 0.007 & 0.268 & & 0.021 & 2.71 & 0.030 & 0.350 & 0.001 & 0.084 \\
\hline
\end{tabular}

Notes:

a $p=0.108$.

$\mathrm{b} p=0.112$.

c Percentage of management/administrative staff organized in teams.

${ }^{\mathrm{d}}$ Percentage of production staff organized in teams.

${ }^{\mathrm{e}}$ When teams do not take time out $=0$; otherwise $=1$.

${ }^{*} p<0.05 ; * * 0<0.01 ;+p<0.10$ 
Table 3. Multiple and Moderated Regression of Innovation in Technical Systems for Lagged (Column I) and Longitudinal (Column II) Effects

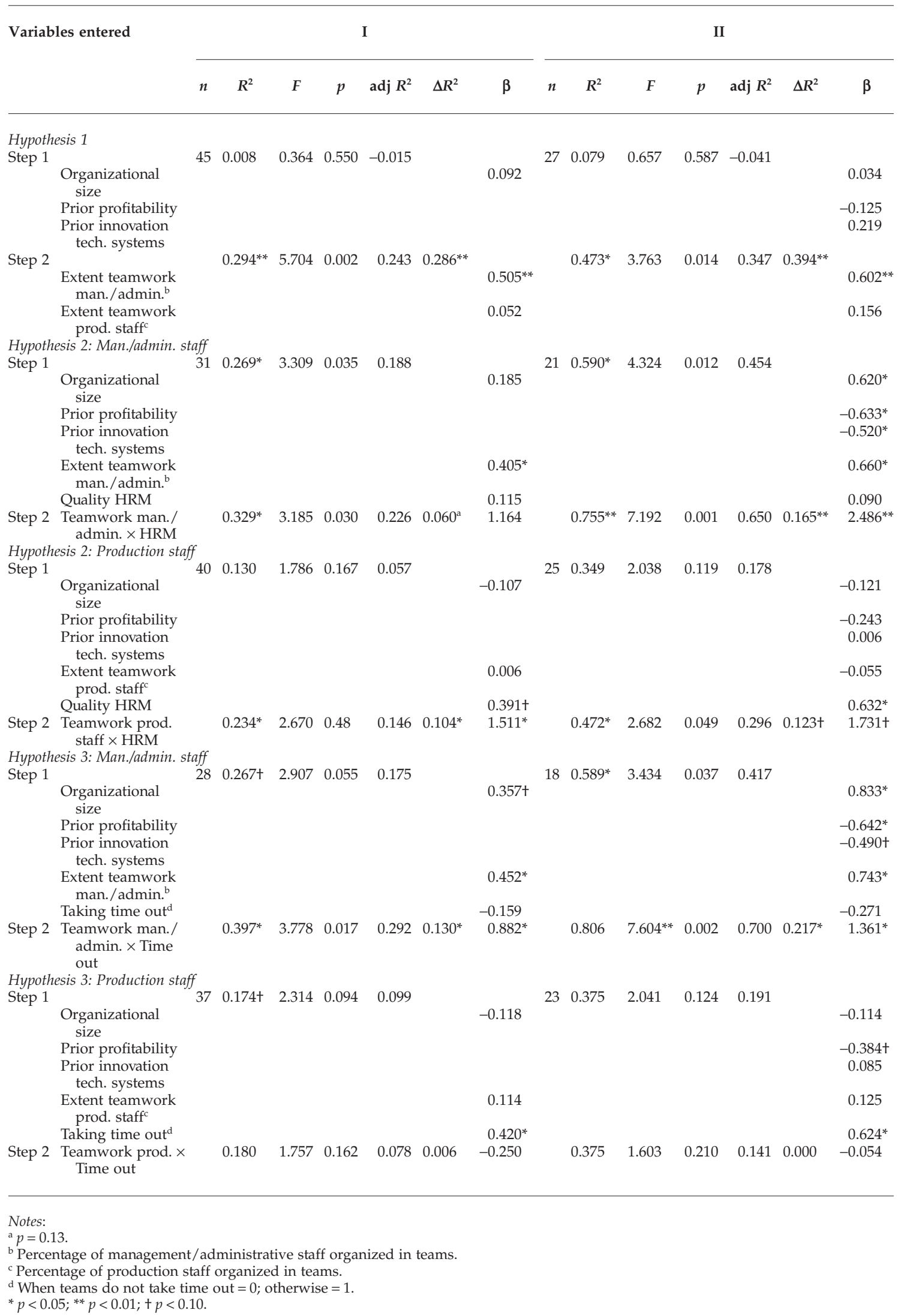




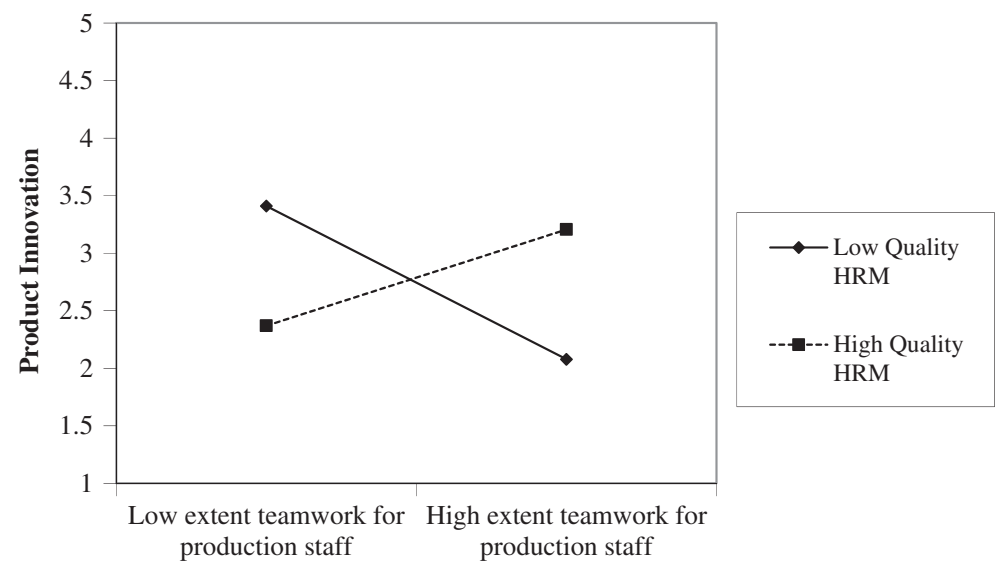

Figure 1. HRM Quality Moderates the Impact of Extent of Teamwork for Production Staff on Product Innovation

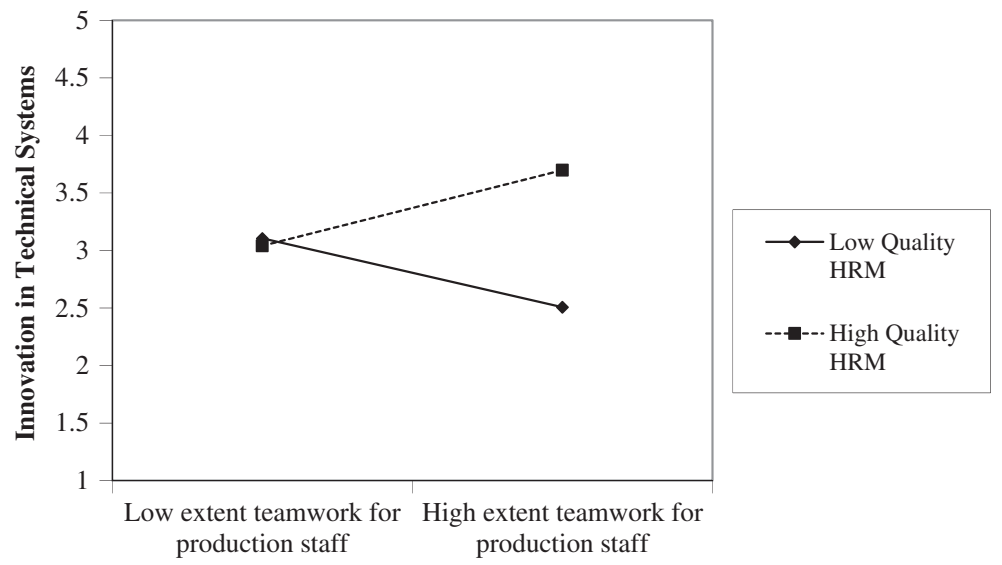

Figure 2. HRM Quality Moderates the Impact of Extent of Teamwork for Production Staff on Innovation in Technical Systems

administrative staff in the lagged analyses (Table 2, column I; product innovation: $\beta=1.113, \Delta R^{2}=0.207, p<0.05$; Table 3, column I; innovation technical systems: $\beta=0.882$, $\left.\Delta R^{2}=0.139, p<0.05\right)$ and the longitudinal analyses (Table 2, column II; product innovation: $\beta=1.335, \Delta R^{2}=0.216, p<0.05$; Table 3, column II; innovation technical systems: $\left.\beta=1.361, \Delta R^{2}=0.217, p<0.05\right)$. No significant interaction effect for production staff emerged.

Plots of the interaction support the hypothesized direction of relationship: increasing levels of teamwork benefit innovation, but only when teams take time out to review their processes (see Figures 3 and 4).

\section{Discussion}

Conceptualizing the HRM systems as a contextual variable that can facilitate or constrain the potentially beneficial effect of teamwork, the purpose of this paper was to study the teamwork/innovation link by specifically exploring the moderating role of the HRM context in which the teams operate. Building on the work of Shipton etal. (2006), our re-analysis showed a significant and positive effect of teamwork for management/ administrative staff on innovation, whereas the effect of teamwork for production staff was negligible. Teamwork for production staff, however, is not without effect for innovation, as the results of the second hypothesis suggest. Increasing teamwork in production workers benefits innovation in organizations that have high-quality HRM systems. Production staff appear to need stronger support to reap the benefits of teamwork. We had put forward that production teams may enhance organizational innovation through their creative contributions in the ideation stage, and particularly 


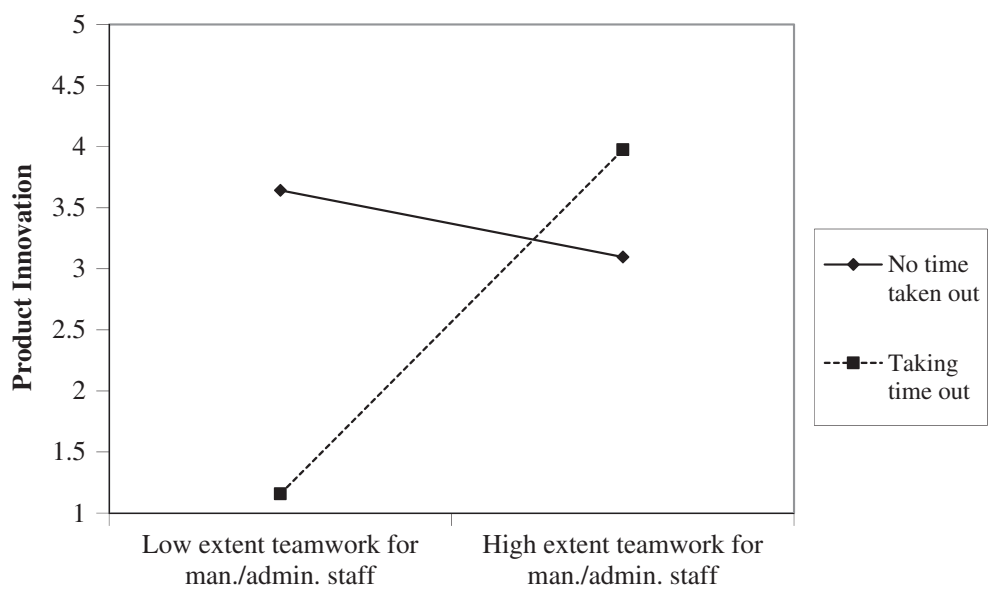

Figure 3. Taking Time Out Moderates the Impact of Extent of Teamwork for Management and Administrative Staff on Product Innovation

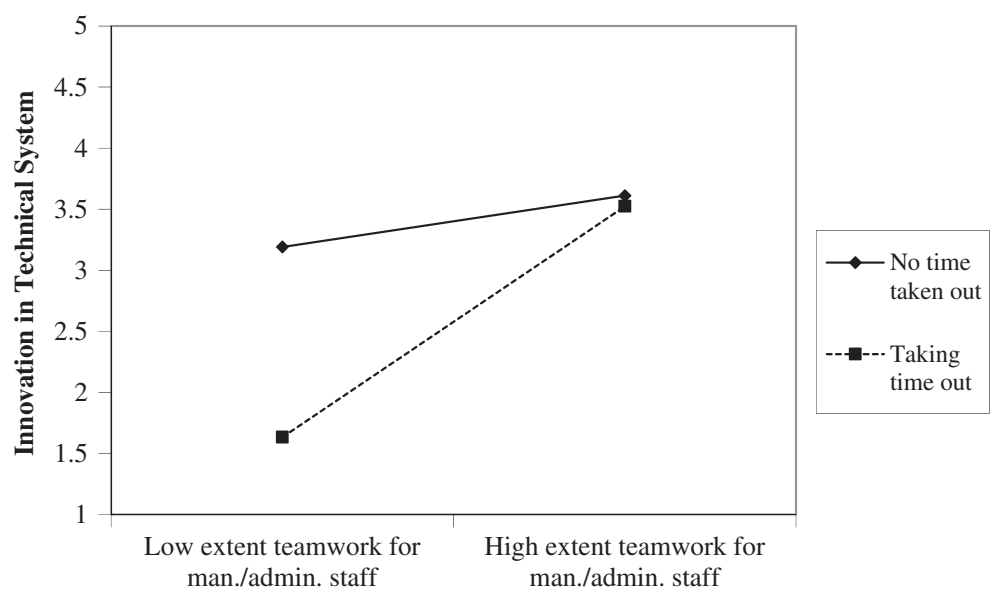

Figure 4. Taking Time Out Moderates the Impact of Extent of Teamwork for Management and Administrative Staff on Innovation in Technical Systems

through their creative problem solving and resilience in the implementation phase of an innovation. In order to benefit from teamwork, the use of production teams needs to be supported through high-quality HRM systems. Future research will have to unravel the underlying processes, for example whether the effect of high-quality HRM systems is based on the systems providing the effective guidance and feedback so that teams can tailor their ideas and contributions towards what the organization exactly needs.

We proposed that one specific HRM practice, use of team reviewing time, could be crucial for teamwork to unfold its positive effects. Results for the last hypothesis suggest that when teams take time out to review their team functioning, then the positive effect of increasing levels of teamwork in management/administrative staff is enhanced. The almost flat slopes for teams not reviewing themselves, as shown in Figures 3 and 4 , even indicate that there is no benefit of increasing the extent of teamwork in this case. We argued that when teams take time out to review, they have time to reflect on things, to question current processes and procedures, and seek feedback on their activities (Schippers, Den Hartog \& Koopman, 2007). Then they have time to actually benefit from their diverse perspectives and expertise. Why do we find this interaction for management/ administrative teams only? Two factors can account for this. First, as pointed out earlier, management teams differ from production teams (among other factors) in their extent of knowledge diversity. Management teams are typically drawn from different functions so 
that individuals are rather diverse in their taskrelevant characteristics such as knowledge, expertise and educational background. Administrative teams also tend to be more diverse than production teams, because of the different types of educational backgrounds they bring to the job. A more varied set of knowledge and expertise is assumed to translate into a greater variety of perspectives which in turn increases creativity and innovation (Bantel \& Jackson, 1989; Wiersema \& Bantel, 1992). But before this can happen, the diverse perspectives need to be reconciled, and processes of social categorization need to be overcome (Kozlowski \& Ilgen, 2006). Furthermore, people need to develop shared mental models before they can actually capitalize on their diversity (Fay et al., 2006) and reflexivity helps achieve this (van Ginkel, Tindale \& van Knippenberg, 2009). Finally, management/administrative teams are likely to be under constant time pressure to achieve day-to-day targets and are therefore likely to benefit significantly from having time out to reflect and plan for future activity.

The second factor accounting for the differential results may be a methodological weakness of the measure of reviewing time for teams. The present measure only assessed the amount of reviewing time; it did not carry any information on how it is used. It is therefore possible that production teams used the reviewing time differently than management/ administrative teams. Future research will have to look into this.

This study provides some suggestions for future research and contributes to the literature in several ways. First, previous research showed that the use of self-directed teams can benefit organizational goals in terms of organizational performance, patient mortality and staff attitudes (Wall \& Clegg, 1981; Wall et al., 1986; West et al., 2002) (see also metaanalysis by Richter, Dawson \& West, 2011). Our research contributes to a slowly growing stream of research that shows that also organizational innovation can benefit from teamwork (Jiang, Wang \& Zhao, 2012). The next steps in this domain of research should try to uncover systematically the process that underlies this effect. We assume - but have not been able to test - that the teamwork/ innovation link is mediated by two processes. Firstly, people organized in teams have higher levels of autonomy and experience more positive affect in comparison with people in traditional structures, both of which amplify creativity, which in turn affects organizational innovation (Jiang, Wang \& Zhao, 2012). Secondly, the implementation of teamwork is associated with structural changes that involve higher organizational flexibility, adaptability and integration, which are in turn associated with higher innovation (Damanpour, 1991; Mohrman, Cohen \& Mohrman, 1995). We have not been able to test whether the teamworkinnovation link is mediated by these affective and structural changes. We could, however, perform supplementary analyses to provide an initial test of the assumption that increasing levels of teamwork are associated with the proposed mediators.

Of the 45 organizations studied here, 25 had also participated in a survey study. This data was used to look at the relationship between the extent to which all staff is organized in teams (ranging from zero to 100 per cent) with job satisfaction, autonomy, departmental integration and flexibility. The measure general job satisfaction covers satisfaction with regard to principal aspects of the job (e.g., pay, colleagues, physical working conditions) (Warr, Cook \& Wall, 1979). Autonomy assesses the extent to which people can make decisions on their own (e.g., 'Management trusts people to take work-related decisions without permission'); departmental integration measures level of departmental co-operation (e.g., 'People in different departments are prepared to share information'); flexibility captures an organization's ability to respond quickly to demands and opportunities (e.g., 'Quick decisions/ actions are characteristic of this place') (Patterson, Warr \& West, 2004).

The relationships between the overall percentage of staff that is organized in teams and the satisfaction/climate variables were $r=0.51$ $(p<0.005)$ for satisfaction, $r=0.36(p<0.040)$ for autonomy, $r=0.31(p=0.067)$ for departmental integration, and $r=0.48(p<0.008)$ for flexibility $(n=25$; one-tailed tests). In other words, the more staff is organized in teams, the higher the job satisfaction in the organization, the higher the experienced autonomy, departmental integration and flexibility. These data provide preliminary support for the proposed affective and structural changes associated with higher levels of teamwork. However, future research needs to look at the full process that mediates the effect of teamwork on innovation.

Our second contribution relates to uncovering the effect of the HRM context in which teams operate (Hackman, 1990; Sundstrom, De Meuse \& Futrell, 1990; Guzzo et al., 1992; Hollenbeck, DeRue \& Guzzo, 2004). While other research has looked at the direct contribution of HRM systems for innovation (e.g., Laursen \& Foss, 2003; Lau \& Ngo, 2004), this research conceptualized HRM as a moderator. At first glance, our results seem to contradict previous findings on HRM making a positive 
contribution to innovation (see the main effect of HRM displayed in Tables 2 and 3, Hypothesis 2, step 1), because there was no significant main effect of quality on HRM. This is due to first, the smaller sample size (note that Hypothesis 2 is tested with organizations only where teamwork is in place) and second, to the strong relationship between levels of teamwork and quality of HRM (see Table 1). In fact, the zero-order correlations of innovation and quality of HRM indicate a substantial relationship $(r=0.32$ and $0.40, p<0.05)$. Our result that HRM is important for teamwork to fulfil its full potential may also explain why other research failed to detect a positive effect of teamwork. For example, Laursen and Foss (2003) did not find a significant effect of the use of interdisciplinary and quality work circles on innovation; exploring the HRM context in which the teams were embedded may help to understand this.

\section{Limitations}

While the present study provides some evidence for the differential effects of teamwork for management/administrative teams and production teams, analyses could not be taken further to analyse differences between management teams and administrative teams, or mixed teams. A differentiation would help to gain insights into the exact leverage points and processes. For example, are teams that comprise both management and administrative staff more important than homogeneous management teams because the former composition is more conducive to a high level of organizational integration (Damanpour, 1991)? Future research will have to explore this in more depth.

Furthermore, we highlighted above that the measure of reviewing time for teams had its weaknesses, since it did not assess the nature of usage. Teams will differ in the way they use away days, and they will differ in the extent to which they develop reflexivity through time away. This is important from a practical point of view: if teams do use reviewing time, this is not a guarantee that they will automatically make effective use of it and benefit in the expected way.

Furthermore, the sample size of the present study is, with $28-45$ and $18-27$ organizations in the lagged and longitudinal analyses, respectively, limited. Results should be replicated with larger samples. This might also help to get a better understanding of the unusual pattern of findings for Hypothesis 2, extent of teamwork for management/administrative staff. The hypothesized moderation emerged for managerial/administrative staff only in the longitudinal, not in the lagged analyses. This pattern is unusual because the statistical power is much smaller in the longitudinal than in the lagged analysis. We performed further analyses to test whether this pattern was the result of a selective bias in the organizations that went into the longitudinal analyses. This was not the case. The emergence of the moderation effect was dependent on controlling for prior productivity and innovation. The benefit of combining teamwork for managerial/administrative staff with HRM unfolds over time only relative to the performance of an organization. This is, however, only a tentative explanation that needs to be substantiated with a larger sample.

\section{Conclusion}

Organizations are increasingly required to initiate and sustain innovation to survive in a turbulent external environment. Our analyses shed a positive light on the use of teamwork as a job design practice for achieving this goal. One needs, however, to bear in mind that teams who underperform and/or even derail are not rare exceptions (Hackman, 1990); instead, extensive research found teamwork failure related to issues like co-ordination and motivation loss or poor decision making (Aldag \& Fuller, 1993; Karau \& Williams, 1993). These are potential threats that can outweigh the benefits of teamwork. Therefore, we would not want our results to be seen as a general encouragement to implement teamwork in all circumstances. Instead, careful consideration has to be given to the nature of the work tasks, the teams' context and to the management of the change process. Organizations need to design the tasks such that they are appropriate for teams (Mohrman, Cohen \& Mohrman, 1995; West \& Markiewicz, 2004; Harris \& Beyerlein, 2005). Furthermore, researchers have provided strategies for capitalizing on the creative potential of teams (Paulus, 2006) and have highlighted the role of task complexity (Pollard \& Kramer, 2004) as a moderator of performance loss (or gains), task importance and team significance to overcome motivation losses (Karau \& Williams, 1993). The present study presents some suggestions on the role of the HRM context, because of its facilitating or constraining nature, for teams to become effective. This is particularly important from a practical point of view given the tendency of organizations to cut first on budgets for HRM if the economic situation gets tight (UPS, 2003): the present results suggests that one puts the potential benefits of teamwork at risk. 


\section{Acknowledgement}

This paper is based on a large data set that was also used by Shipton et al., 2005, 2006; Patterson et al., 2004. We are grateful to Jeremy Dawson for his comments on an earlier version of this paper. An earlier version of this paper was presented at the 45th conference of DGPs (German Psychological Society), 2006, 17-21 September, Erlangen-Nuernberg, Germany.

\section{References}

Aiken, L.S. and West, S.G. (1991) Multiple Regression: Testing and Interpreting Interactions. Sage, Newbury Park, CA.

Aldag, R.J. and Fuller, S.R. (1993) Beyond Fiasco: A Reappraisal of the Groupthink Phenomenon and a New Model of Group Decision Processes. Psychological Bulletin, 113, 533-52.

Amabile, T.M. (1996) Creativity in Context. Westview Press, Boulder, CO.

Ancona, D.G. and Caldwell, D.F. (1992) Demography and Design: Predictors of New Product Team Performance. Organization Science, 3, 321-41.

Anderson, N. and King, N. (1993) Innovation in Organizations. In Cooper, C.L. and Robertson, I.T. (Eds.), International Review of Industrial and Organizational Psychology. Wiley, Chichester, pp. 1-34.

Applebaum, E., Bailey, T., Berg, P. and Kalleberg, A.L. (2000) Manufacturing Advantage: Why High Performance Work Systems Pay Off. Cornell University Press, Ithaca, NY.

Banbury, C.M. and Mitchell, W. (1995) The Effect of Introducing Important Incremental Innovations on Market Share and Business Survival. Strategic Management Journal, 16, 161-82.

Bantel, K.A. and Jackson, S.E. (1989) Top Management and Innovations in Banking: Does the Composition of the Top Team Make a Difference? Strategic Management Journal, 10, 107-24.

Basadur, M. and Gelade, G.A. (2006) The Role of Knowledge Management in the Innovation Process. Creativity and Innovation Management, 15, 45-62.

Benders, J., Huijgen, F. and Pekruhl, U. (2002) What Do We Know About the Incidence of Group Work (if anything)? Personnel Review, 31, 371-86.

Chaney, P. and Devinney, T. (1992) New Product Innovations and Stock Price Performance. Journal of Business Finance $\mathcal{E}$ Accounting, 19, 677-95.

Cohen, S.G. and Bailey, D.E. (1997) What Makes Teams Work: Group Effectiveness Research from the Shop Floor to the Executive Suite. Journal of Management, 23, 239-90.

Cully, M., Woodland, S., O'Reilly, A. and Dix, G. (1999) Britain at Work: As Depicted by the 1998 Workplace Employee Relations Survey. Routledge, London.

Damanpour, F. (1991) Organizational Innovation: A Meta-Analysis of Effects of Determinants and Moderators. Academy of Management Journal, 34, 555-90.
Damanpour, F. (1996) Organizational Complexity and Innovation: Developing and Testing Multiple Contingency Models. Management Science, 42, 693-716.

Damanpour, F. (2010) An Integration of Research Findings of Effects of Firm Size and Market Competition on Product and Process Innovations. British Journal of Management, 21, 996-1010.

Damanpour, F. and Schneider, M. (2006) Phases of the Adoption of Innovation in Organizations: Effects of Environment, Organization and Top Managers. British Journal of Management, 17, 21536.

Davis, M.A. (2009) Understanding the Relationship between Mood and Creativity: A Meta-Analysis. Organizational Behavior and Human Decision Processes, 108, 25-38.

De Dreu, C.K.W. (2002) Team Innovation and Team Effectiveness: The Importance of Minority Dissent and Reflexivity. European Journal of Work and Organizational Psychology, 11, 285-98.

Den Hartog, D.N. and Verburg, R.M. (2004) High Performance Work Systems, Organisational Culture and Firm Effectiveness. Human Resource Management Journal, 14, 55-78.

Fay, D., Borrill, C., Amir, Z., Haward, R. and West, M.A. (2006) Getting the Most out of Multidisciplinary Teams: A Multi-Sample Study of Team Innovation in Health Care. Journal of Occupational $\mathcal{E}$ Organizational Psychology, 79, 553-67.

Gersick, C.J. (1988) Time and Transition in Work Teams: Toward a New Model of Group Development. Academy of Management Journal, 31, 9-41.

Gersick, C.J. (1989) Marking Time: Predictable Transitions in Task Groups. Academy of Management Journal, 32, 274-309.

Gevers, J.M.P., van Eerde, W. and Rutte, C.G. (2001) Time Pressure, Potency, and Progress in Project Groups. European Journal of Work and Organizational Psychology, 10, 205-21.

Guthrie, J.P. (2001) High Involvement Practices, Turnover and Productivity: Evidence from New Zealand. Academy of Management Journal, 44, 180 90.

Guzzo, R.A., Shea, G.P., Dunnette, M.D. and Hough, L.M. (1992) Group Performance and Intergroup Relations in Organizations. In Dunnette, M.D. and Hough, L.M. (Eds.), Handbook of Industrial and Organizational Psychology, Vol. 3, 2nd edn. Consulting Psychologists Press, Palo Alto, CA, pp. 269-313.

Hackman, J.R. (1990) Groups that Work (and those that don't). Jossey Bass, San Francisco, CA.

Harris, C.L. and Beyerlein, M.M. (2005) Team-Based Organization: Creating an Environment for Team Success. In West, M.A., Tjosvold, D. and Smith, K.G. (Eds.), The Essentials of Teamworking. Wiley, Chichester, pp. 149-71.

Hollenbeck, J.R., DeRue, D.S. and Guzzo, R. (2004) Bridging the Gap between I/O Research and HR Practice: Improving Team Composition, Team Training and Team Task Design. Human Resource Management, 43, 353-68.

Horwitz, S.K. and Horwitz, I.B. (2007) The Effects of Team Diversity on Team Outcomes: A MetaAnalytic Review of Team Demography. Journal of Management, 33, 987-1015. 
Hülsheger, U.R., Anderson, N. and Salgado, J.F. (2009) Team-Level Predictors of Innovation at Work: A Comprehensive Meta-Analysis Spanning Three Decades of Research. Journal of Applied Psychology, 94, 1128-45.

Huselid, M.A. (1995) The Impact of Human Resource Management Practices on Turnover, Productivity, and Corporate Financial Performance. Academy of Management Journal, 38, 63572.

Isen, A.M., Daubman, K.A. and Nowicki, G.P. (1987) Positive Affect Facilitates Creative Problem Solving. Journal of Personality and Social Psychology, 52, 1122-31.

Jackson, S.E. (1996) The Consequences of Diversity in Multidisciplinary Work Teams. In West, M.A. (Ed.), Handbook of Work Group Psychology. John Wiley \& Sons, London, pp. 53-75.

Jiang, J., Wang, S. and Zhao, S. (2012) Does HRM Facilitate Employee Creativity and Organizational Innovation? A Study of Chinese Firms. International Journal of Human Resource Management, 23, 4025-47.

Karau, S.J. and Williams, K.D. (1993) Social Loafing: A Meta-Analytic Review and Theoretical Integration. Journal of Personality and Social Psychology, $65,681-706$.

King, N. (1992) Modelling the Innovation Process: An Empirical Comparison of Approaches. Journal of Occupational and Organizational Psychology, 65, 89-100.

Klein, K.J., Bliese, P.D., Kozlowski, S.W.J., Danserau, F., Gavin, M.B., Griffin, M.A., et al. (2000) Multilevel Analytical Techniques: Commonalities, Differences, and Continuing Questions. In Klein, K.J. and Kozlowski, S.W.J. (Eds.), Multilevel Theory, Research and Methods in Organizations. Jossey-Bass, San Francisco, CA, pp. 512-53.

Klein, K.J. and Sorra, J.S. (1996) The Challenge of Innovation Implementation. Academy of Management Review, 21, 1055-80.

Kozlowski, S.W.J. and Ilgen, D.R. (2006) Enhancing the Effectiveness of Work Groups and Teams. Psychological Science in the Public Interest, 7, 77-124.

Lau, C.-M. and Ngo, H.-Y. (2004) The HR System, Organizational Culture, and Product Innovation. International Business Review, 13, 685-703.

Lau, D.C. and Murnighan, J.K. (2005) Interactions within Groups and Subgroups: The Effects of Demographic Faultlines. Academy of Management Journal, 48, 645-59.

Laursen, K. and Foss, N.J. (2003) New Human Resource Management Practices, Complementarities and the Impact on Innovation Performance. Cambridge Journal of Economics, 27, 243-63.

MacCurtain, S., Flood, P.C., Ramamoorthy, N., West, M.A. and Dawson, J.F. (2010) The Top Management Team, Reflexivity, Knowledge Sharing and New Product Performance: A Study of the Irish Software Industry. Creativity and Innovation Management, 19, 219-32.

Mannix, E. and Neale, M.A. (2005) What Differences Make a Difference? The Promise and Reality of Diverse Teams in Organizations. Psychological Science in the Public Interest, 6, 31-55.
March, J.G. (1991) Exploration and Exploitation in Organizational Learning. Organization Science, 2, 71-87.

Mathieu, J.E., Heffner, T.S., Goodwin, G.F., Salas, E. and Cannon-Bowers, J.A. (2000) The Influence of Shared Mental Models on Team Process and Performance. Journal of Applied Psychology, 85, 273-83.

Milliken, F.J. and Martins, L.L. (1996) Searching for Common Threads: Understanding the Multiple Effects of Diversity in Organizational Groups. Academy of Management Review, 21, 402-33.

Mohrman, S.A., Cohen, S.G. and Mohrman, A.M., Jr. (1995) Designing Team-Based Organizations: New Forms for Knowledge Work. Jossey-Bass, San Francisco, CA.

Mohrman, S.A. and Mohrman, A.M.J. (1994). LargeScale Organizational Change as Learning: Creating Team-Based Organizations. Paper presented at the Corporate Change: An International Research Conference.

Mohrman, S.A. and Quam, K. (2000) Consulting to Team-Based Organizations: An Organizational Design and Learning Approach. Consulting Psychology Journal: Practice and Research, 52, 20-35.

Morgeson, F.P., Johnson, M.D., Campion, M.A., Medsker, G.J. and Mumford, T.V. (2006) Understanding Reactions to Job Redesign: A QuasiExperimental Investigation of the Moderating Effects of Organizational Context on Perceptions of Performance Behaviour. Personnel Psychology, 59, 333-63.

Naveh, E. and Erez, M. (2004) Innovation and Attention to Detail in the Quality Improvement Paradigm. Management Science, 50, 1576-86.

Patterson, M., Warr, P. and West, M. (2004) Organizational Climate and Company Productivity: The Role of Employee Affect and Employee Level. Journal of Occupational and Organizational Psychology, 77, 193-216.

Paulus, P.B. (2006) Putting the Brain Back into Brainstorming. Associations Now, 2, 24-28.

Pfeffer, J. (1998) The Human Equation, Building Profits by Putting People First. Harvard University Press, Boston, MA.

Pollard, A. and Kramer, T.J. (2004) The Nature of Tasks: Taking Group Brainstorming to New Levels. Paper presented at the SIOP, Chicago, IL, 2-4 April.

Reagans, R., Argote, L. and Brooks, D. (2005) Individual Experience and Experience Working Together: Predicting Learning Rates from Knowing Who Knows What and Knowing How to Work Together. Management Science, 51, 86981.

Richter, A.W., Dawson, J.F. and West, M.A. (2011) The Effectiveness of Teams in Organizations: A Meta-Analysis. International Journal of Human Resource Management, 22, 2749-69.

Schippers, M.C., Den Hartog, D.N. and Koopman, P.L. (2007) Reflexivity in Teams: A Measure and Correlates. Applied Psychology: An International Review, 56, 189-211.

Shipton, H., Fay, D., West, M.A., Patterson, M.G. and Birdi, K. (2005) Managing People to Promote Innovation. Creativity and Innovation Management, 14, 118-28. 
Shipton, H., West, M.A., Dawson, J.F., Birdi, K. and Patterson, M. (2006) HRM as a Predictor of Innovation. Human Resource Management Journal, 16, 3-27.

Somech, A. (2006) The Effects of Leadership Style and Team Process on Performance and Innovation in Functionally Heterogeneous Teams. Journal of Management, 32, 132-57.

Sundstrom, E., De Meuse, K.P. and Futrell, D. (1990) Work Teams. American Psychologist, 45, 120-33.

Trott, P. (2005) Innovation Management and New Product Development, 3rd edn. Pearson, Harlow.

Un, C.A. and Cuervo-Cazurra, A. (2004) Strategies for Knowledge Creation in Firms. British Journal of Management, 15, 27-41.

UPS (2003) UPS Europe Business Monitor Executive Summary XIII [WWW document]. URL: http:/ / www.ebm.ups.com/europe/ebmxiii/img/ EBMXIII_UK.pdf [accessed 27 November 2014].

Urbach, T., Fay, D. and Goral, A. (2010) Extending the Job Design Perspective on Individual Innovation: Exploring the Effect of Group Reflexivity. Journal of Occupational and Organizational Psychology, 83, 1053-64.

van de Ven, A.H. (1986) Central Problems in the Management of Innovation. Management Science, 32, 590-607.

van Ginkel, W., Tindale, R.S. and van Knippenberg, D. (2009) Team Reflexivity, Development of Shared Task Representations, and the Use of Distributed Information in Group Decision Making. Group Dynamics: Theory, Research, and Practice, 13, 265-80.

Wall, T.D. and Clegg, C.W. (1981) A Longitudinal Field Study of Group Work Redesign. Journal of Occupational Behavior, 2, 31-49.

Wall, T.D., Kemp, N.J., Jackson, P.R. and Clegg, C.W. (1986) Outcomes of Autonomous Workgroups: A Long-Term Field Experiment. Academy of Management Journal, 29, 280-304.

Warr, P.B., Cook, J. and Wall, T.D. (1979) Scales for the Measurement of Some Work Attitudes and Aspects of Psychological Well-Being. Journal of Occupational Psychology, 52, 129-48.

West, M.A., Borrill, C., Dawson, J., Scully, J., Carter, M., Anelay, S., et al. (2002) The Link Between the Management of Employees and Patient Mortality in Acute Hospitals. International Journal of Human Resource Management, 13, 1299-310.

West, M.A. and Markiewicz, L. (2004) Building Team-Based Working: A Practical Guide to Organizational Transformation. Blackwell Publishing, Malden, MA.

West, M.A., Patterson, M., Lawthorn, R. and Maitlis, S. (1999) The Sheffield Effectiveness Programme: A Description of Methods. Working Paper, Aston Business School.

Wiersema, M.F. and Bantel, K.A. (1992) Top Management Team Demography and Corporate
Strategic Chance. Academy of Management Journal, 35, 91-121.

Zaltman, G., Duncan, R. and Holbek, J. (1973) Innovations and Organizations. Wiley, New York.

Doris Fay (doris.fay@uni-potsdam.de) is Full Professor of Work and Organizational Psychology at the University of Potsdam, Germany. She received her PhD from the University of Amsterdam, The Netherlands, and was employed as Lecturer and Senior Lecturer at Aston Business School, UK. Her research interests include creativity and innovation, proactivity and personal initiative, and well-being at work. Her work has been published in international journals such as Journal of Applied Psychology, Journal of Occupational and Organizational Psychology, Human Performance and Applied Psychology: An International Review.

Helen Shipton (helen.shipton@ntu.ac.uk) is Professor of International HRM at Nottingham Business School, Nottingham Trent University, UK. Before that she was employed as Senior Lecturer (2007-13) and Lecturer (2003-07) at Aston Business School, UK. Her research interests are focused on HRM, creativity and innovation; in particular, how HRM is signalled by senior managers and perceived by employees. Helen led an ESRC seminar series focused on HRM, innovation and performance and has published in journals such as Human Resource Management, Human Resource Management Journal, Journal of Organizational Behaviour and Journal of International Business Studies.

Michael A. West (m.a.west@lancaster .ac.uk) is Professor of Organizational Psychology at Lancaster University Management School, Emeritus Professor at Aston University and Senior Fellow at The King's Fund, London. His research focuses on culture, teams, innovation and performance, and on the organization and delivery of health services.

Malcolm Patterson (m.patterson@ sheffield.ac.uk) is a Senior Research Fellow at the Institute of Work Psychology, Management School, University of Sheffield. He has research interests in the areas of organizational culture, employee affect and wellbeing. He has published in leading journals such as Academy of Management Journal, Journal of Management, Journal of Organizational Behavior and Personnel Psychology. 